\title{
DRAINAGE AREAS, HARTFORD NORTH QUADRANGLE, CONNECTICUT
}

\author{
By \\ Mendall P. Thomas
}

FOLIO OF THE HARTFORD NORTH QUADRANGLE, CONNECTICUT MAP I-784 J

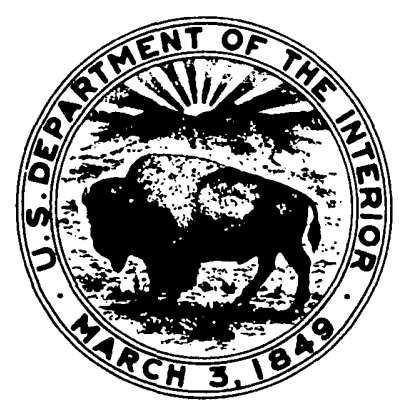

